\title{
Direct Shear Strength on the São Francisco River Bank, Northeastern Brazil, With or Without Roots of Different Native Species
}

\author{
Igor Pinheiro da Rocha \\ Iande, Av. Jorge Amado, 1565, Jardins, Aracaju-SE, Brazil. E-mail: \\ igor@ipsustentabilidade.com
}

Francisco Sandro Rodrigues Holanda (Corresponding author)

Universidade Federal de Sergipe, Av. Marechal Rondon, s/n, CEP 49100-000, Jardim Rosa Elze, São Cristóvão - SE, Brazil. E-mail: fholanda@infonet.com.br

Mario Monteiro Rolim

Universidade Federal Rural de Pernambuco, Rua Dom Manoel de Medeiros, s/n, Dois Irmãos, CEP 52171-900, Recife, PE, Brazil. E-mail: mario.rolim@ gmail.com

\section{Alceu Pedrotti}

Universidade Federal de Sergipe, Av. Marechal Rondon, s/n, CEP 49100-000, Jardim Rosa Elze, São Cristóvão - SE, Brazil. E-mail: alceupedrotti@gmail.com

\section{Marks Melo Moura}

Universidade Federal do Paraná, Av. Pref. Lothário Meissner, 632, CEP 80210-170, Jardim Botânico, Campus III, Curitiba (PR). E-mail: marksmoura@yahoo.com.br

\section{Luiz Diego Vidal Santos}

Universidade Federal de Sergipe, Av. Marechal Rondon, s/n, CEP 49100-000, Jardim Rosa Elze, São Cristóvão - SE, Brazil. E-mail: vidal.center@academico.ufs.br 


\section{Abstract}

Several plant species have been studied as reinforcement elements against landslides at slopes, either to protect against the splash effect offered by shoots or anchoring the soil by the root system. The objective of this work was to investigate the influence of roots from shrub species over the soil mechanical attributes such as cohesion and angle of internal friction at the São Francisco riverbank, northeastern Brazil. A trench was excavated under the treetop of every shrubby individual, sampling blocks at $0-0.25,0.25-0.50,0.50-0.75$, and $0.75-1.00 \mathrm{~m}$ depths. The moisture contents, particle size, liquidity limits, plasticity and actual specific mass of the samples were determined. The soil physical and mechanical attributes such as initial and final specific weight, initial and final void content, initial and final degree of saturation, shear resistance peaks, cohesion, and internal friction angle were identified through direct, elementary, consolidated, and undrained tests. In the samples with Solanum paniculatum, Mimosa pigra species, the highest values for cohesion were registered for the samples with roots. Sesbania virgata presented the greatest variation in cohesion and internal friction angle among samples with and without roots. The position and root status influenced the results of the direct shear tests.

Keywords: root cohesion, internal friction angle, riverbank erosion, Solanum paniculatum, Mimosa pigra Sesbania virgata

\section{Introduction}

Riverbank slopes can be stabilized by controlling the erosion process requiring the use of techniques that can be widely adapted to water basins in order to promote aesthetic and ecological improvements and to guarantee agricultural production in non-degraded areas associated of riverbanks (Abedini, Said, \& Ahmad, 2012).

In some points of the sedimentary stretch on the lower São Francisco Riverbank, the erosion magnitude rate can vary between 5 to 300m per year (Holanda et al., 2007; Rocha et al., 2018). The margin retreat lines are directly related to the energy of the natural waves, caused by the winds, soil mass movement on the slopes and hydrological events, as well as the variation of the flow, the variation of the height and the velocity of the flow (Ribeiro et al., 2011; L. Wang, Guo, \& Wang, 2020). This, associated with the physical attributes of the slope in each section of the river, leads to the larger erosion rates at certain times of the year and in specific stretches (Martins-Oliveira et al., 2020). As mentioned by Holanda et al. (2005) it causes several consequences changing environmental landscape and reducing the crop area of irrigated agro ecosystems, dominated by small farmers and affecting the river navigation.

The use of slope recovery plants, mainly for geotechnical stabilization, demands characteristics that allow their development in these places. These characteristics include rapid growth, drought tolerance, deep root system, vigorous growth, wide availability of seeds, easy dissemination, survival in soils with low fertility and effective soil cover (Hamidifar et al., 2018; Lyda et al., 2017). Some species have been widely studied as important alternatives to control the erosion process on slopes and river banks, because their root systems can provide stability (Vannoppen et al., 2017). 


\section{Macrothink

The root systems contributes to the stability of the slopes, works in special emphasis on the mechanical effects (Kokutse et al., 2016; Nguyen et al., 2019). When soils are subjected to shear effects, roots mobilize their tension resistance and act as anchors, then the shear stresses in the soil matrix are transferred to the roots (Meijer et al., 2019), which reinforces the soil mechanical resistance to tension (Correa et al., 2019; Leung et al., 2018).

Soil shear resistance (r), expressed by Coulomb's equation, is a function of the cohesion and the friction angle among the soil parameters (Lambe, 1951), which are intrinsic to the soil and are defined by their properties and attributes such as texture, structure, organic matter content, specific weight, mineralogy, and moisture content. Several authors agree that a plant root system may significantly influence the parameters related to the soil shear resistance (Ghestem et al., 2014; Stokes et al., 2014). Velinova et al. (2019), stated that plant roots tend to gather with the soil to form a monolithic mass that contributes to an increase in resistance, which generates an apparent cohesion. Thus, if the soil contains roots, the increased resistance to the soil shear may be expressed as additional cohesion.

Mao et al. (2012), reported that the density and architectural characteristics of roots are likely more important than their mechanical cohesion characteristics. However, many authors support the theory that shear resistance in the soil is primarily a product of stiffness and tensile strength of the roots (Alam et al., \& Baral, 2018; Ganapathy et al., 2019; Moshi et al., 2020). The resistance of soils that contain roots may be inspected directly in situ (Baranska et al., 2005; Carvalho| et al., 2020) or through laboratory tests such as direct shear tests (Kokutse et al., 2016; Qi \& Tang, 2018).

Despite of large plant species biodiversity at the Lower São Francisco River, there is a lack of information about which ones can be used in soil bioengineering designs, considering the suitable species features related to its mechanical properties. Thus, the objective of this work was to investigate the influence of roots from native shrub species over the soil mechanical attributes such as cohesion and angle of internal friction at the São Francisco riverbank, Brazil.

\section{Method}

\subsection{Study Site}

This study was conducted at the experimental site located in the banks of the São Francisco river, in the municipality of Amparo de São Francisco, Sergipe state, Brazil (Figure 1). This bank is composed of sedimentary alluvial soil classified as Fluvic Entisol by the Soil Taxonomy (Soil Survey Staff, 2014). 


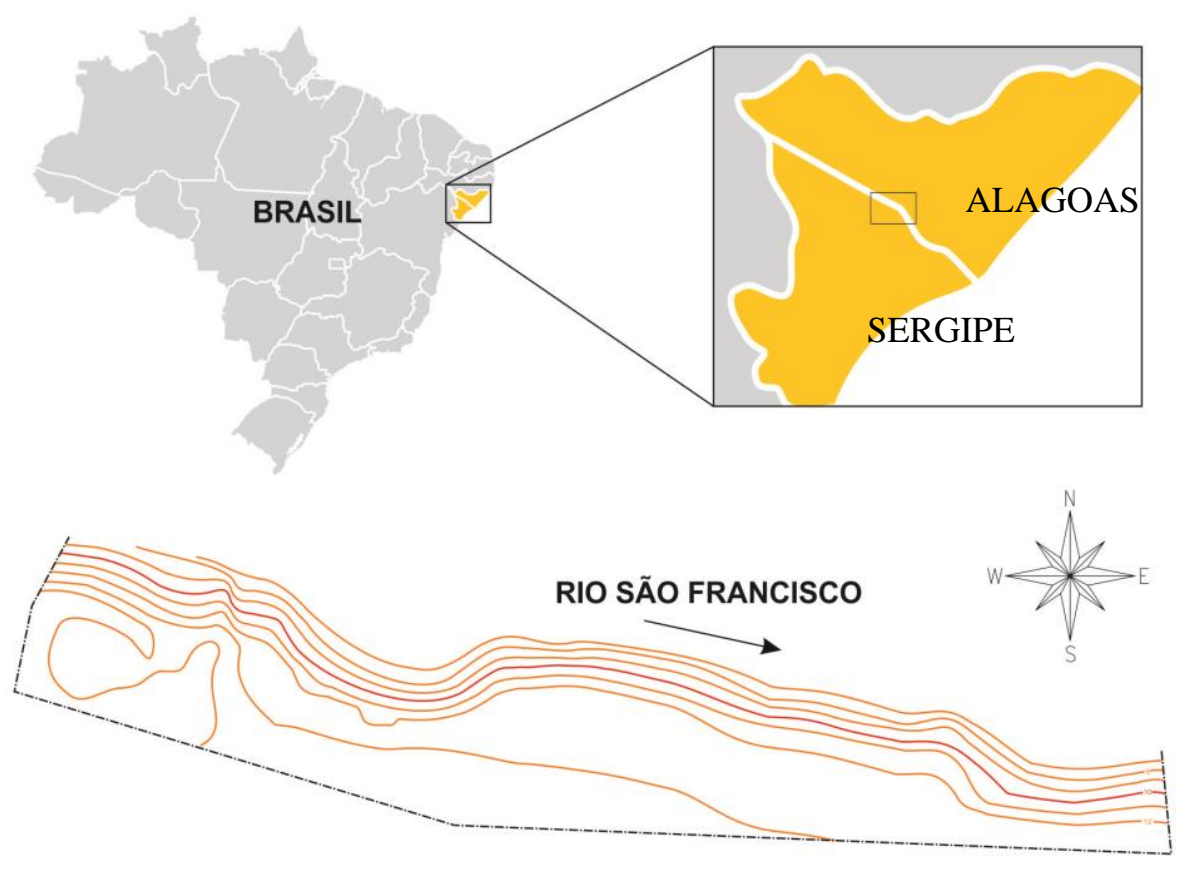

Figure 1. Location of the study site.

This region has a warm and humid climate with an annual mean temperature of $25^{\circ} \mathrm{C}$. Rainfall ranges from 800 to $1300 \mathrm{~mm}$ in rainy season occurs during the winter, between March and September.

The research area was originally dominated by native riparian vegetation included in the Atlantic Rain Forest biome. During the last decades the original vegetation was gradually replaced by pasture and tillage.

In July 2010, soil-bioengineering techniques were installed in an experimental design. In these tests, intense soil mechanical operations mostly related to soil cutting and landfill in order to provide the slope reshaping resulted in extensive soil mobilization in the riverbank slope and in the associated flat area. This is about an area of $200 \mathrm{~m} \times 30 \mathrm{~m}$ in length and width, respectively, and a slope of 27 degrees. During this period, the present vegetation, mostly composed by shrub invasive species, was clear cutted as a result of the slope reshaping, and the bank was planted partially with species such as vetiver grass (Chrysopogon zizanioides (L.) Nash) and other previously studied species to provide erosion control by its mechanical reinforcement. In 2012, prior to the beginning of this study, numerous plant species bloomed throughout the area due to the seed dissemination from the surrounding areas.

\subsection{Species Selection}

Some species were previously selected from the local biogeography (Franco, 1983), a plant survey conducted exclusively for shrub-sized plants. This botanical material was collected and preserved, and the species were identified in the ASE herbarium at Universidade Federal 
de Sergipe (Nascimento, 2015). The survey resulted in a list of 10 potential species with desirable biotechnical characteristics. However, due to the availability of samples in satisfactory overall condition (Petrone \& Preti, 2013) and time for excavation to collect soil blocks (Böhm, 2012), only the three most frequent species were selected: Solanum paniculatum, Sesbania virgata and Mimosa pigra.

Solanum paniculatum L., a native Brazilian species commonly known as "Jurubeba", is an angiosperm of the Solanaceae botanical family. It is a perennial shrubby, erect, branched species $1 \mathrm{~m}-2 \mathrm{~m}$ tall exhibiting pubescent and curved spine stems, and its flowers have white petals and yellow anthers. Originally, from northern and northeastern regions, this species is present throughout the entire Brazilian territory, commonly found in pastures, crops, orchards, roadsides, tracks, and wastelands. It generally occurs in sandy and dry soils (Ferreira, Valente, $\&$ Santos, 2017). In soil excavations, this species roots achieve $0.63 \mathrm{~m}$ depth.

Sesbania virgata (Cav.), a native tropical species from Brazil, is part of the Fabaceae botanical family and has the botanical synonym of Sesbania marginata Benthan. Commonly known as "Sesbânia", it is a perennial, fast-growth shrubby plant. It is $2 \mathrm{~m}$ to $4 \mathrm{~m}$ tall and naturally occurs on riverbanks, floodplains, and modified soil (Sartori, Pott, Pott, \& de Carvalho, 2018). This species produces a large quantity of long-term viable seeds dispersed in indehiscent fruits in the form of pods and has been used to re-vegetate riparian woods, soil erosion control, and recover degraded areas (Salis et al., 2004). In soil excavations, this species roots achieve $0.78 \mathrm{~m}$ depth.

Mimosa pigra L. is a native species of tropical environments and belongs to the Fabaceae botanical family. It is shrubby and erect and can reach up to $6 \mathrm{~m}$ in height. Its steam has thorns up to $7 \mathrm{~mm}$ long, its leaves are bipinnated with up to 16 pairs of 5-cm long pinnae. The seeds are able to germinate throughout the year and germination normally occurs in humid soil that has not flooded. It has a fast growth, and its flowering occurs 4 to 12 months after germination (Lonsdale, Harley, \& Gillett, 1988). In soil excavations, this species roots achieve $0.87 \mathrm{~m}$ depth.

After selecting the individual with the best overall condition among each species, its root system was excavated and sampled and then submitted to direct shear strength tests.

\subsection{Soil Sample}

A trench was excavated under the treetop of every shrubby specimen, sampling four soil blocks measuring $25 \times 25 \times 25 \mathrm{~cm}$, at $0-0.25,0.25-0.50,0.50-0.75$, and $0.75-1.00 \mathrm{~m}$ depths from the soil surface, with a total of 12 blocks (four for each species). These blocks were paraffined and packed in wooden boxes to protect them during transportation.

\subsection{Soil Characterization}

The preparation of each intact block containing soil and soil permeated by roots and determination of the moisture content of the samples were conducted in accordance with the Brazilian Standard NBR 6457 (ABNT, 1986). The sieve analysis was conducted in accordance with the NBR 7181 Standard (ABNT, 1984d), and tests for determining liquidity 
and plasticity limits were conducted in accordance with NBR 6459 (ABNT, 1984a) and NBR 7180 (ABNT, 1984c) standards, respectively. The prescribed method in NBR 6508 (ABNT, 1984b) standard was used to determine the actual specific mass density.

\subsection{Direct Shear Test}

The soil physical and mechanical attributes such as initial and final specific weight, initial and final void content, initial and final degree of saturation, shear resistance peaks, cohesion, and internal friction angle were identified through direct, elementary, consolidated, and undrained tests (CU).

The tests were performed at the Geotechnical and Paving Laboratory (GEOPAV) of the Civil Engineering Department at 'Universidade Federal de Sergipe' in accordance with the D6528 (American Society for Testing and Materials, 2017) standard by employing a direct shear conventional press (Wille Geotechnik LO 2900). The horizontal displacement speed used in the tests was in accordance with the recommendation presented in the standard, which demands that the elapsed time necessary for obtaining the desired shear is twice that needed to obtain $90 \%$ consolidation of the species, which must be determined for each test. In this case, the established speed was superior to $0.05 \mathrm{~mm} \mathrm{~min}^{-1}$. Therefore, in order to optimize testing times, this value was adopted as the standard shear speed in every test.

Four samples (blocks) containing only local soil and four samples (blocks) containing roots of the selected species were extracted of each intact soil block by using metallic rings $(\varnothing=60$ $\mathrm{mm} \times \mathrm{H}=20 \mathrm{~mm}$ ), using a small blade to gradually to remove the soil excess. To simulate the average levels of effective geostatic vertical stresses in the studied slope, these species were submitted to normal stresses $(\sigma)$ of $5 \mathrm{kPa}, 11 \mathrm{kPa}, 21 \mathrm{kPa}$, and $42 \mathrm{kPa}$, which were determined on the basis of the specific weight of the soil and the sample depth (Stokes \& Mattheck, 1996).

The samples were saturated by flooding for 30 seconds. During the consolidation phase of each test, readings were made after $0.1,0.25,0.5,1,2,4,8,15,30,60,90$, and $120 \mathrm{~min}$. During the shear stage, readings were made every $0.5 \mathrm{~min}$ until reaching $5 \mathrm{~min}$, every minute until reaching $10 \mathrm{~min}$, every $10 \mathrm{~min}$ until reaching $30 \mathrm{~min}$ and so on until reaching $30 \mathrm{~min}$ every $30 \mathrm{~min}$. In this slow direct shear test with pre-consolidation, soil deformations were also measured (Figure 2). 


\section{$\Lambda$ Macrothink}
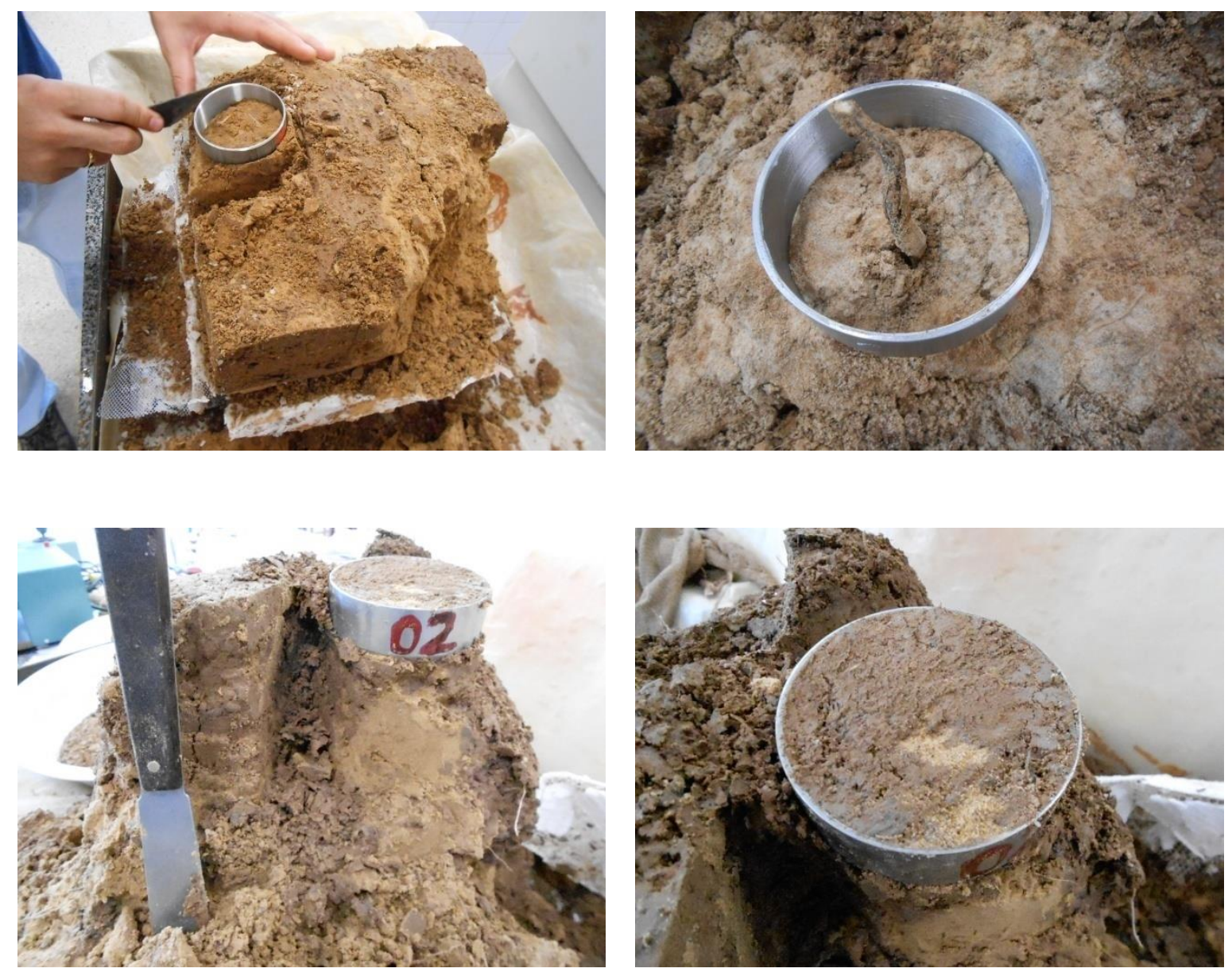

Figure 2. Sequence of procedures to perform the direct shear tests

After completing the tests, the resistance envelope was obtained for every applied normal stress by using Coulomb's equation. It was then possible to determine the values for the cohesion and internal friction angle of the soil for samples with and without roots.

\subsection{Direct Shear Test}

To evaluate the physical and mechanical attributes of the soil such as specific weight, cohesion, and internal friction angle, an experiment with a randomized block design (DBC) was performed that included two treatments (with or without roots), four blocks (depths: $0-0.25 ; 0.25-0.50 ; 0.50-0.75$ and $0.75-1.00 \mathrm{~m}$ ), and four block replications. The results were subjected to an analysis of variance and means comparison using Tukey's test with a 5\% probability. Additionally, a correlation analysis between the resulting lines from the direct shear test in the samples with and without roots was conducted in accordance with the method described by Snedecor and Cochran (1989).

\section{Results}

\subsection{Soil Sample Characterization}

The typical behavior of alluvial soils, which were formed by deposition of highly varied grain 
size layers (Gonzales, Dahlin, Barmen, \& Rosberg, 2016; Jordanova, Goddu, Kotsev, \& Jordanova, 2013), was not observed in the studied profiles. Although small variation between the soil constituents were reported, all of the blocks were predominantly formed by silt and were classified as CL under the Unified Soil Classification System, indicating inorganic clay with low compressibility (Table 1).

Table 1. Soil sample characterization on the profiles with Solanum paniculatum, Sesbania virgata and Mimosa pigra

\begin{tabular}{|c|c|c|c|c|c|c|}
\hline \multirow{2}{*}{ Species } & \multirow{2}{*}{ Depth (m) } & \multicolumn{4}{|c|}{ Granulometry $\left(\mathrm{g} \mathrm{kg}^{-1}\right)$} & \multirow{2}{*}{$\omega \mathrm{P}$} \\
\hline & & Gravel & Sand & Silt & Clay & \\
\hline \multirow{5}{*}{ Solanum panicu } & 0 to 0.25 & 10 & 120 & 540 & 330 & 13 \\
\hline & 0.25 to 0.5 & 0.0 & 120 & 510 & 370 & 20 \\
\hline & & & & & & \\
\hline & 0.5 to 0.75 & 0.0 & 10 & 510 & 480 & 22 \\
\hline & 0.75 to 1.0 & 0.0 & 120 & 580 & 300 & 14 \\
\hline \multirow{5}{*}{ Sesbania virg } & 0 to 0.25 & 0.0 & 140 & 510 & 350 & 14 \\
\hline & 0.25 to 0.5 & 0.0 & 130 & 390 & 480 & 15 \\
\hline & & & & & & \\
\hline & 0.5 to 0.75 & 0.0 & 30 & 680 & 290 & 21 \\
\hline & 0.75 to 1.0 & 0.0 & 100 & 640 & 260 & 16 \\
\hline \multirow{5}{*}{ Mimosa pig } & 0 to 0.25 & 0.0 & 120 & 610 & 270 & 18 \\
\hline & 0.25 to 0.5 & 10 & 140 & 520 & 330 & 17 \\
\hline & & & & & & \\
\hline & 0.5 to 0.75 & 0.0 & 80 & 630 & 290 & 18 \\
\hline & 0.75 to 1.0 & 0.0 & 20 & 560 & 420 & 23 \\
\hline
\end{tabular}

\subsection{Direct Shear Tests}

As expected, the sheaths of the root-permeated specimens exhibited different behaviors relative to those that did not contain roots, revealing an irregular rupture plane in those that contained roots and rectilinear in those that did not have roots (Figure 3). 


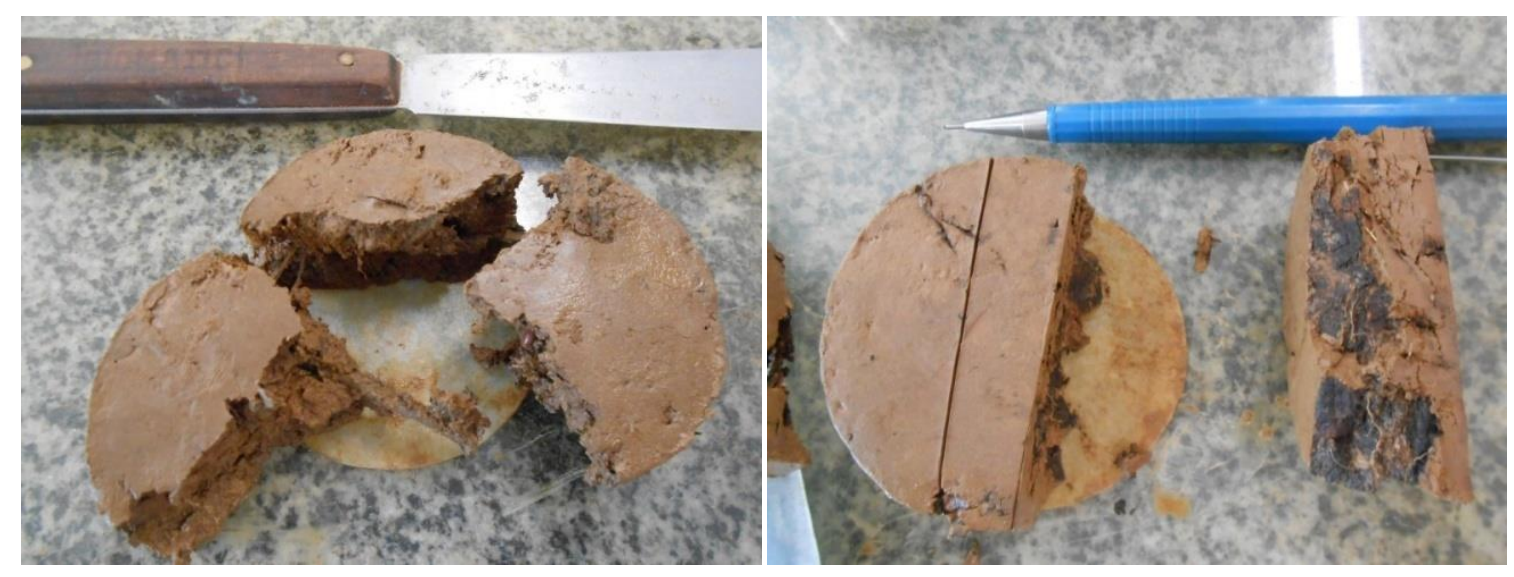

Figure 3. Permeate (A) and non-root permeate (B) samples by roots

The species presented distinct behaviors in the effect of roots on the cohesion, internal friction angle, and initial specific weight for the different depths (Table 2).

Table 2: Cohesion values ( $\mathrm{c}-\mathrm{kPa})$, internal friction angle $\left(\varphi-{ }^{\circ}\right)$ and initial density $(\rho-\mathrm{kg}$ $\mathrm{dm}-3$ ) resulting from direct shear tests for specimens with and without roots of Solanum paniculatum, Sesbania virgata and Mimosa pigra

\begin{tabular}{|c|c|c|c|c|c|c|c|}
\hline \multirow[b]{2}{*}{ Depth (m) } & & \multicolumn{2}{|c|}{ S. paniculatum } & \multicolumn{2}{|c|}{ S. virgata } & \multicolumn{2}{|c|}{ M. pigra } \\
\hline & & $\begin{array}{l}\text { with } \\
\text { roots }\end{array}$ & $\begin{array}{c}\text { without } \\
\text { roots }\end{array}$ & $\begin{array}{l}\text { with } \\
\text { roots }\end{array}$ & $\begin{array}{c}\text { without } \\
\text { roots }\end{array}$ & $\begin{array}{l}\text { with } \\
\text { roots }\end{array}$ & $\begin{array}{c}\text { without } \\
\text { roots }\end{array}$ \\
\hline \multirow{3}{*}{0 to 0.25} & $\mathrm{c}$ & 8.1 & 8.5 & 5.6 & 5.0 & 11.7 & 8.8 \\
\hline & $\phi$ & 15.6 & 30.8 & 39.2 & 21.9 & 33.4 & 40.1 \\
\hline & $\rho$ & $\begin{array}{c}1.88 \\
\mathrm{aA} \\
\end{array}$ & $1.89 \mathrm{aA}$ & $1.91 \mathrm{aA}$ & $1.86 \mathrm{aA}$ & $\begin{array}{c}1.67 \\
\mathrm{aA}\end{array}$ & $1.74 \mathrm{aA}$ \\
\hline \multirow{3}{*}{0.25 to 0.50} & $\mathrm{c}$ & 11.6 & 7.5 & 0.5 & 3.6 & 23.2 & 7.1 \\
\hline & $\phi$ & 32.7 & 22.8 & 33.7 & 27.9 & 11.9 & 41.4 \\
\hline & $\rho$ & $\begin{array}{c}1.86 \\
\mathrm{aA}\end{array}$ & $1.87 \mathrm{aA}$ & $1.86 \mathrm{aA}$ & $1.89 \mathrm{aA}$ & $\begin{array}{c}1.58 \\
\mathrm{aA}\end{array}$ & $1.71 \mathrm{aA}$ \\
\hline \multirow{3}{*}{0.50 to 0.75} & $\mathrm{c}$ & 11.6 & 8.1 & 12.4 & 15.8 & 21.3 & 18.0 \\
\hline & $\phi$ & 25.7 & 33.5 & 19.3 & 28.5 & 11.6 & 25.9 \\
\hline & $\rho$ & $\begin{array}{c}1.61 \\
\mathrm{aA}\end{array}$ & $1.63 \mathrm{aA}$ & $1.63 \mathrm{aA}$ & $1.60 \mathrm{aA}$ & $\begin{array}{c}1.58 \\
\mathrm{aA}\end{array}$ & $1.6 \mathrm{aA}$ \\
\hline \multirow{3}{*}{0.75 to 1.0} & $\mathrm{c}$ & 7.4 & 0.07 & 13.7 & 5.8 & 9.3 & 14.6 \\
\hline & $\phi$ & 15.9 & 16.4 & 22.0 & 34.2 & 22.6 & 34.9 \\
\hline & $\rho$ & $\begin{array}{c}1.26 \\
\mathrm{aB}\end{array}$ & $1.32 \mathrm{aB}$ & $1.31 \mathrm{aB}$ & $1.33 \mathrm{aB}$ & $\begin{array}{c}1.28 \\
\mathrm{aB}\end{array}$ & $1.31 \mathrm{aB}$ \\
\hline
\end{tabular}

Means followed by the same lower case letters in a line and capital letters on the columns do not differ significantly by the Tukey test $(\mathrm{p}<0.05)$.

In the samples with Solanum paniculatum species, the highest values for $c$ were registered for the samples with roots except for the $0-0.25 \mathrm{~m}$ depth, where $c$ was higher for the samples 
without roots. The values for $c$ for samples without roots presented a little variation until the $0.75 \mathrm{~m}$ depth, at which the lowest cohesion of this study was observed at $0.07 \mathrm{kPa}$. Values close to zero are attributed to soils with extremely low clay content (Hubble, Airey, Sealey, De Carli, \& Clarke, 2013), which was not the case for these samples (Table 2).

Conversely, $\phi$ was always lower for samples with roots except for the $0.25-0.50 \mathrm{~m}$ depth, in which $\phi$ was lower for samples without roots. Samples with Sesbania virgata presented the greatest variation in $\mathrm{c}$ and $\phi$ among samples with and without roots. It is important to note that the lowest value for $c, 0.5 \mathrm{kPa}$, was recorded for samples with roots at depths of $0.25-0.50 \mathrm{~m}$.

Samples with Mimosa pigra presented the highest values of $c$ among the samples with roots for depths of $0.25-0.50 \mathrm{~m}$ and $0.50-0.75 \mathrm{~m}$; $\phi$ was always lower for samples with roots. However, it is important to point out that the lowest values for $c$ were recorded for samples with roots of S. virgata at $0.25-0.50 \mathrm{~m}$ and of $M$. pigra at $0.75-1.0 \mathrm{~m}$, in comparison to those without roots. For both cases, the obtained results are incompatible with the high fine contents recorded for both soil samples (Table 1).

While the tests were conducted, every sample, with or without roots, was submitted to the same moisture conditions of saturation. In addition, the contained soil in both sample groups (with or without roots) came from the same block; therefore, the unusual behavior can be caused only by the roots.

After the testing, it was observed that the sample with $S$. virgata, submitted to normal stress of $11 \mathrm{kPa}$, had a root segment $4 \mathrm{~mm}$ in diameter in the collapsed surface in the same direction as the shear. The sample of M. pigra, also submitted to normal stress of $11 \mathrm{kPa}$, showed decomposing thin roots.

The unexpected behaviors of the samples of $S$. virgata, at depths of $0.25-0.50 \mathrm{~m}$, and $M$. pigra, at $0.75-1.0 \mathrm{~m}$, both subjected to a normal stress of $11 \mathrm{kPa}$, may be verified by comparing the lower horizontal deformations with those samples subjected to normal tension of $5 \mathrm{kPa}$, for which lower horizontal deformation values were expected (Figure 4). 

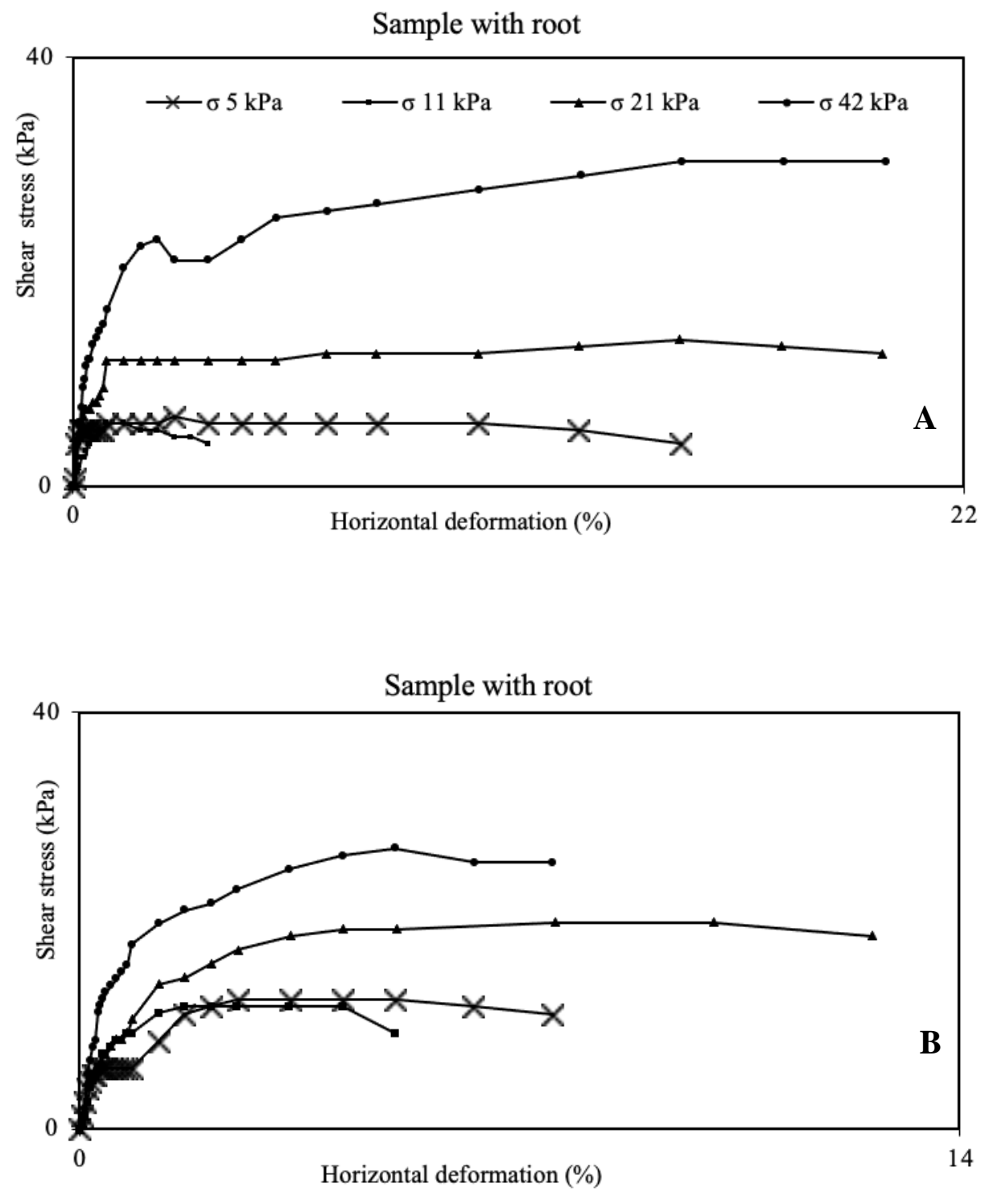

Figure 4. Samples of horizontal deformation with roots of the species (A) Sesbania virgata at depths of $0.25 \mathrm{~m}$ to $0.50 \mathrm{~m}$ and (B) Mimosa pigra at $0.75 \mathrm{~m}$ to $1.0 \mathrm{~m}$, submitted to normal tensions of $5,11,21$, and $42 \mathrm{kPa}$

For $\phi$, however, the samples without roots had higher mean values, about $30 \%$, than those of samples with roots (Table 3).

Table 3. Mean cohesion values (c, $\mathrm{kPa})$ and soil internal friction angle $\left(\phi,{ }^{\circ}\right)$ for samples with and without roots

\begin{tabular}{ccc}
\hline & $\mathrm{c}(\mathrm{kPa})$ & $\phi\left(^{\circ}\right)$ \\
\cline { 2 - 3 } With roots & $11.38 \mathrm{a}$ & $21.21 \mathrm{~b}$ \\
Without roots & $8.57 \mathrm{a}$ & $29.86 \mathrm{a}$ \\
\hline
\end{tabular}

Means followed by the same lower case letters on the columns do not differ significantly by the 


\section{1) Macrothink}

Tukey test $(\mathrm{p}<0.05)$.

Evidence for such effects may be observed in the linear regression line formed by the envelopes of samples with roots of $S$. virgata at depths of $0.25-0.50 \mathrm{~m}$ and $M$. pigra at 0.75-1.0 $\mathrm{m}$ when subjected to normal stress of $11 \mathrm{kPa}$.

Although linear regression lines presented good coefficients of determination at $\mathrm{R}^{2}=0.96$ and $\mathrm{R}^{2}=0.95$, the low peak resistance values attained by the samples underestimated the values of cohesion intercepts, consequently producing a higher value of $\phi$.

Another significant aspect concerns the soil specific weight. Although widely constituted by silt and clay particles, samples that were extracted from blocks at greater depths presented lower specific weight values (Table 2), showing a significant difference between depths of 0.0-0.75 $\mathrm{m}$ and 0.75-1.0 m. Moreover, no statistical differences were observed between samples with and without roots.

The absence of a pattern explaining the effects of roots in the evaluated species may be verified in the envelope of shear resistance for each soil block at the studied depths (Figures 3 to 5).

For the Solanum paniculatum species, at 0-0.25 $\mathrm{m}$ depth, the lowest value and the shear resistance peak of the samples without roots were 9.75 and $31.85 \mathrm{kPa}$, respectively. The difference between these values justifies the slope of the regression straight line, which made it possible to determine the values of $c$ and $\phi$ as $8.54 \mathrm{kPa}$ and $30.81^{\circ}$, respectively for these samples. For samples with roots, the lowest value and the shear resistance peak were 9.1 and $18.85 \mathrm{kPa}$, respectively, for normal stresses of 5 and $42 \mathrm{kPa}$, which made it possible to determine the values of $8.1 \mathrm{kPa}$ and $15.62^{\circ}$ for $\mathrm{c}$ and $\phi$. These results demonstrate that at such depths, both $\mathrm{c}$ and $\phi$ are lower when roots of this species are present (Figure 5).

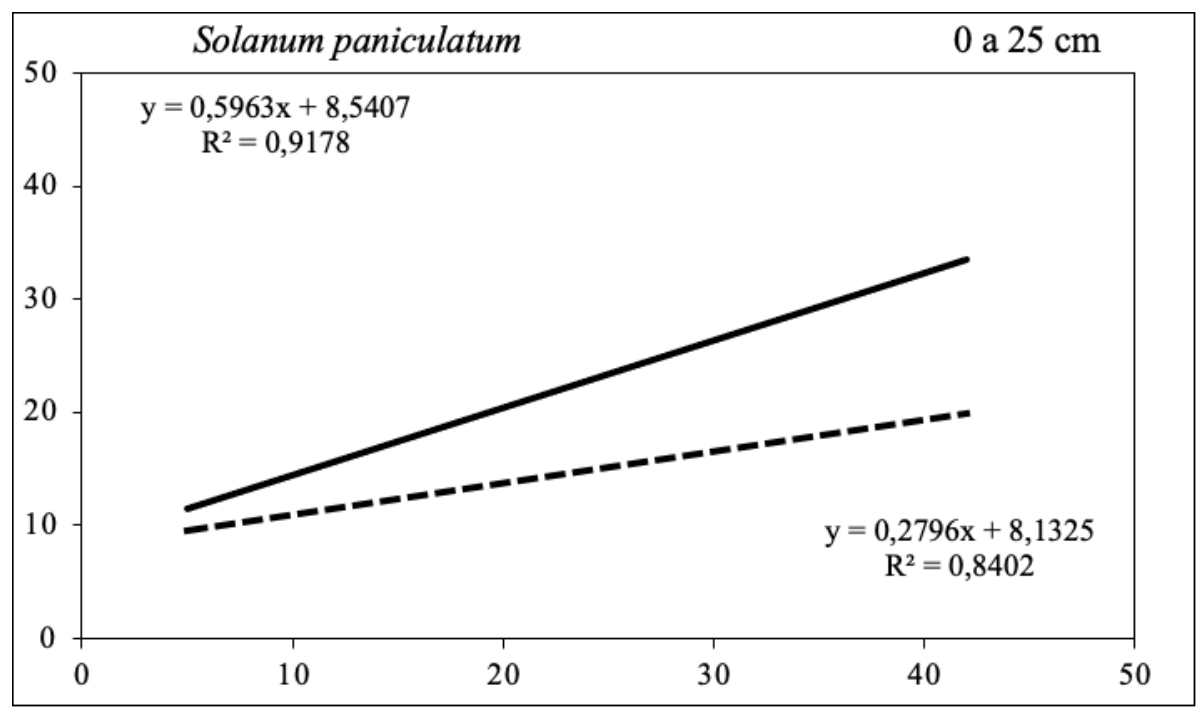



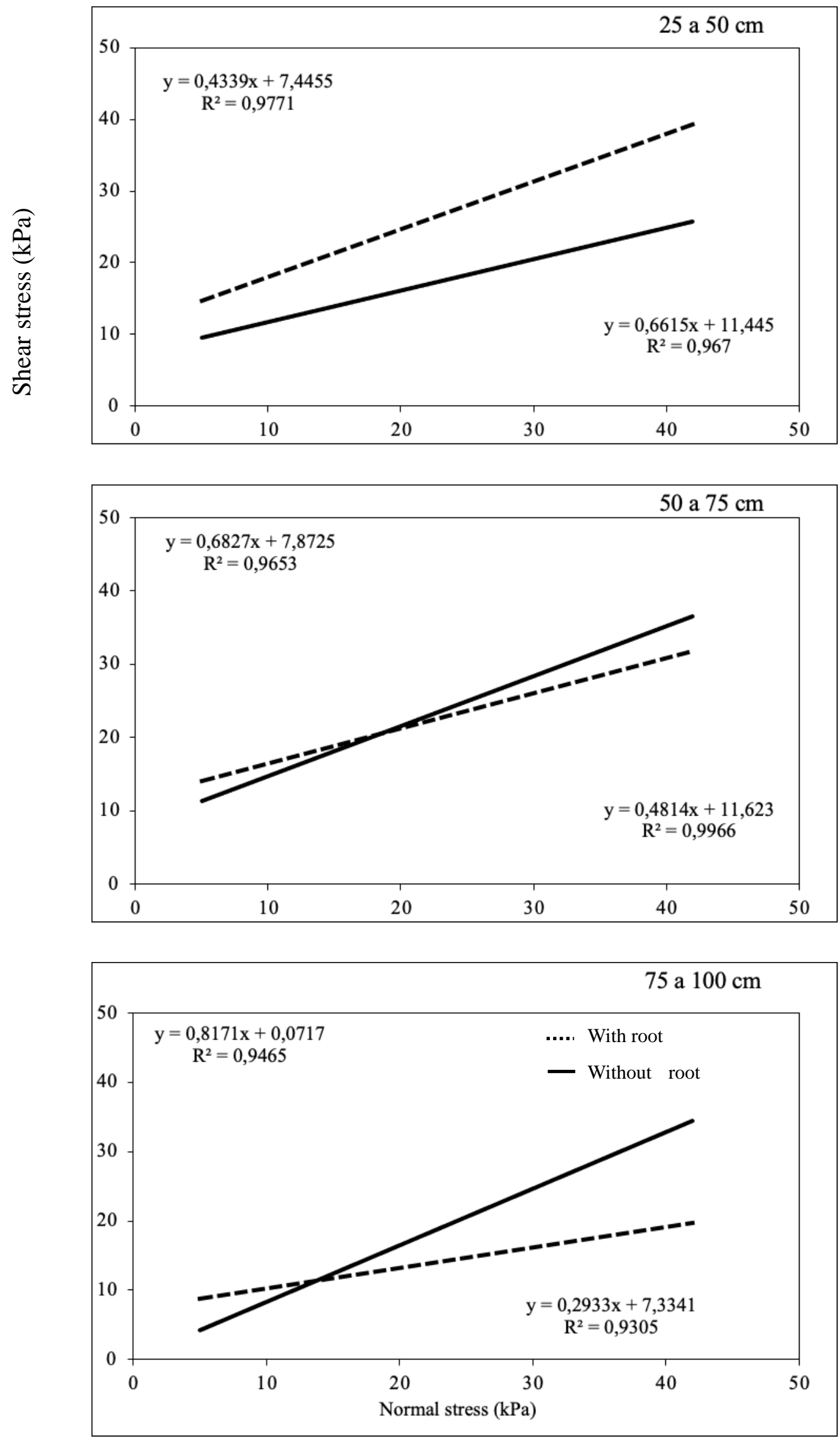


\section{Macrothink}

Figure 5. Normal and shear stress for samples of Solanum paniculatum with and without roots for depths of (A) $0 \mathrm{~m}$ to $0.25 \mathrm{~m}$, (B) $0.25 \mathrm{~m}$ to $0.50 \mathrm{~m}$, (C) $0.50 \mathrm{~m}$ to $0.75 \mathrm{~m}$, and(D)

\section{$0.75 \mathrm{~m}$ to $1.0 \mathrm{~m}$}

For depths of $0.25-0.50 \mathrm{~m}$, the attained lowest values and shear resistance peaks were 8.5 and $25.5 \mathrm{kPa}$, respectively, for samples without roots and 12.39 and $38.49 \mathrm{kPa}$, respectively, for those with roots. The corresponding values for $c$ and $\phi$ were $7.57 \mathrm{kPa}$ and $22.8^{\circ}$ for samples without roots and $11.6 \mathrm{kPa}$ and $3.67^{\circ}$ for those with roots. For this depth, a lower value for $\phi$ and a higher value for $c$ were observed when roots of this species were present.

For depths of $0.50-0.75 \mathrm{~m}$, samples without roots have a lowest resistance value of $10.4 \mathrm{kPa}$ and a shear resistance peak of $35.36 \mathrm{kPa}$. The samples with roots showed the lowest resistance value, $13.65 \mathrm{kPa}$, and a shear resistance peak of $31.85 \mathrm{kPa}$. For samples without roots, the obtained values of $c$ and $\phi$ were $8.1 \mathrm{kPa}$ and $33.5^{\circ}$, respectively; for samples with roots, the obtained values were $11.6 \mathrm{kPa}$ and $25.7^{\circ}$. At these depths, a lower $\phi$ and a higher value for $c$ were observed when roots of this species were present.

At depths of $0.75-1.0 \mathrm{~m}$, the minimum and the maximum shear resistance of the samples without roots were 7.82 and $35.36 \mathrm{kPa}$, respectively, with corresponding normal stress of 5 and $42 \mathrm{kPa}$. The $c$ value was $0.07 \mathrm{kPa}$, and $\phi$ was 16.37 degrees $\left(^{\circ}\right)$. In the samples with roots, the minimum value and the maximum shear resistance were 7.2 and $19.05 \mathrm{kPa}$, respectively. Values of $7.33 \mathrm{kPa}$ and $15.88^{\circ}$ were obtained for $c$ and $\phi$. These results show that this specimen has a lower value of $\phi$ and a higher value of $c$, at such depths, and in the presence of roots.

The profile of the species Sesbania virgata had a shear envelope with slopes that were similar for samples with and without roots at every depth except for 0-0.25 m (Figure 6).

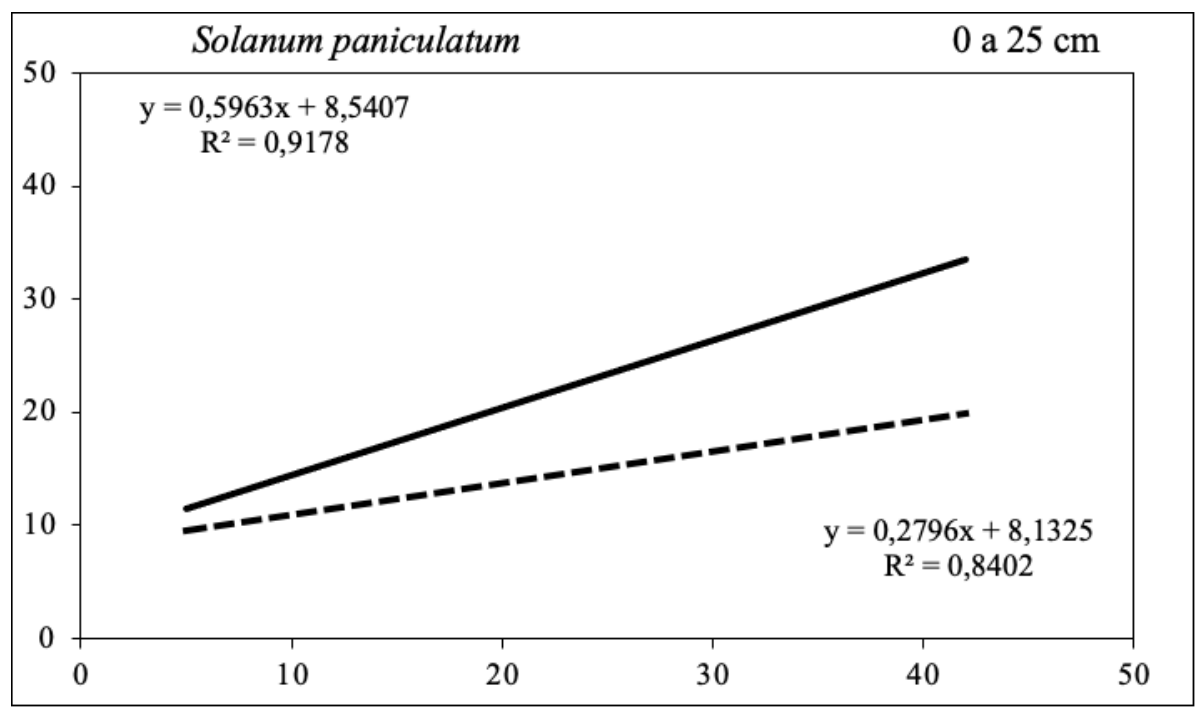



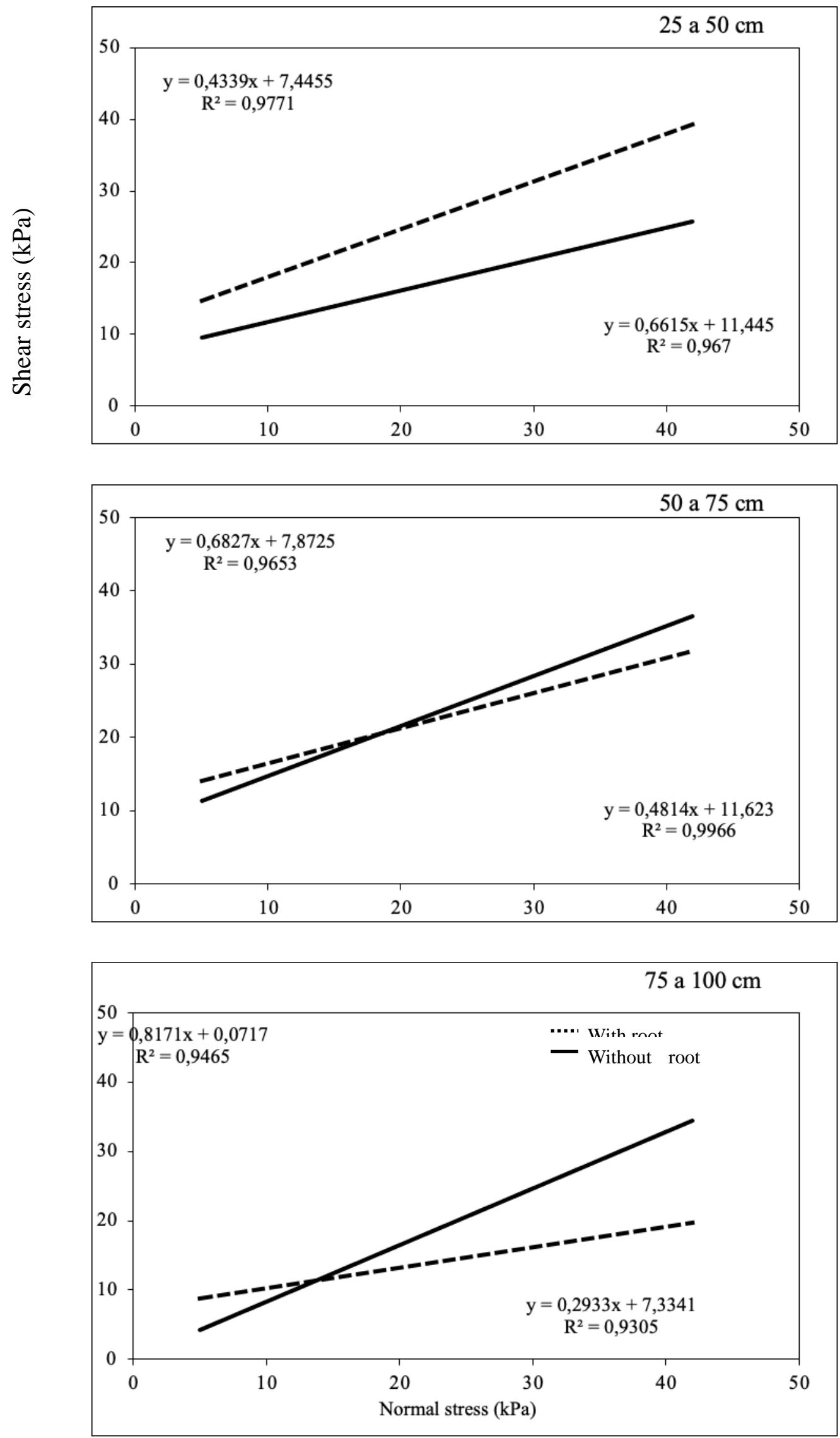


\section{Macrothink

Figure 6. Shear and normal stress for samples of Sesbania virgata with and without roots at depths of (A) $0 \mathrm{~m}$ to $0.25 \mathrm{~m}$, (B) $0.25 \mathrm{~m}$ to $0.50 \mathrm{~m}$, (C) $0.50 \mathrm{~m}$ to $0.75 \mathrm{~m}$, and (D) $0.75 \mathrm{~m}$ to

$$
1.0 \mathrm{~m}
$$

At depths of $0.25-0.50 \mathrm{~m}$, the minimum and the maximum shear resistance of the samples without roots were 5.85 and $26.26 \mathrm{kPa}$, respectively, with corresponding normal stress of 5 and $42 \mathrm{kPa}$. The values of $c$ and $\phi$ determined from the slope of the line were $3.65 \mathrm{kPa}$ and $27.9^{\circ}$, respectively. In the samples with roots, the minimum and maximum shear resistance obtained were 6.5 and $30.2 \mathrm{kPa}$, respectively, with corresponding normal stress of 5 and 42 $\mathrm{kPa}$. The values of $c$ and $\phi$ were $0.5 \mathrm{kPa}$ and $33.75^{\circ}$, respectively. These results show that the value of $c$ is lower and the value of $\phi$ is higher for this species in the presence of roots.

At depths of 0.50-0.75 m, the minimum and the maximum shear resistance for the samples without roots were 18.99 and $40.6 \mathrm{kPa}$, respectively. For the samples with roots, the obtained values were 12.39 and $27.4 \mathrm{kPa}$. In both cases, the normal shear of 5 and $42 \mathrm{kPa}$ was considered. These results indicate $c$ values of $15.8 \mathrm{kPa}$ and $12.42 \mathrm{kPa}$ for samples without roots and with roots, respectively. The results of $\phi$ were $28.5^{\circ}$ for samples with roots and $19.32^{\circ}$ for those without roots.

At depths $0.75-1.0 \mathrm{~m}$, the minimum and the maximum shear resistance for the samples without roots were 7.8 and $33.27 \mathrm{kPa}$, respectively, with corresponding normal stress of 5 and $42 \mathrm{kPa}$. Along with these values, it was possible to calculate the values of $c, 5.79 \mathrm{kPa}$, and $\phi$, $34.18^{\circ}$. For the samples with roots, the values were 15.6 and $31.31 \mathrm{kPa}$ for minimum and maximum shear resistance with normal stress of 5 and $42 \mathrm{kPa}$, respectively. As a result, we determined a $c$ value of $13.72 \mathrm{kPa}$ and a $\phi$ value of $22.01^{\circ}$. These results show that lower values of $\phi$ and higher values of $c$ occurred in the presence of roots.

The profile of Mimosa pigra species at depths up to $0.75 \mathrm{~m}$ showed higher c values in the presence of roots. In bigger depths, greater cohesion was attributed to the sample without roots (Figure 7).

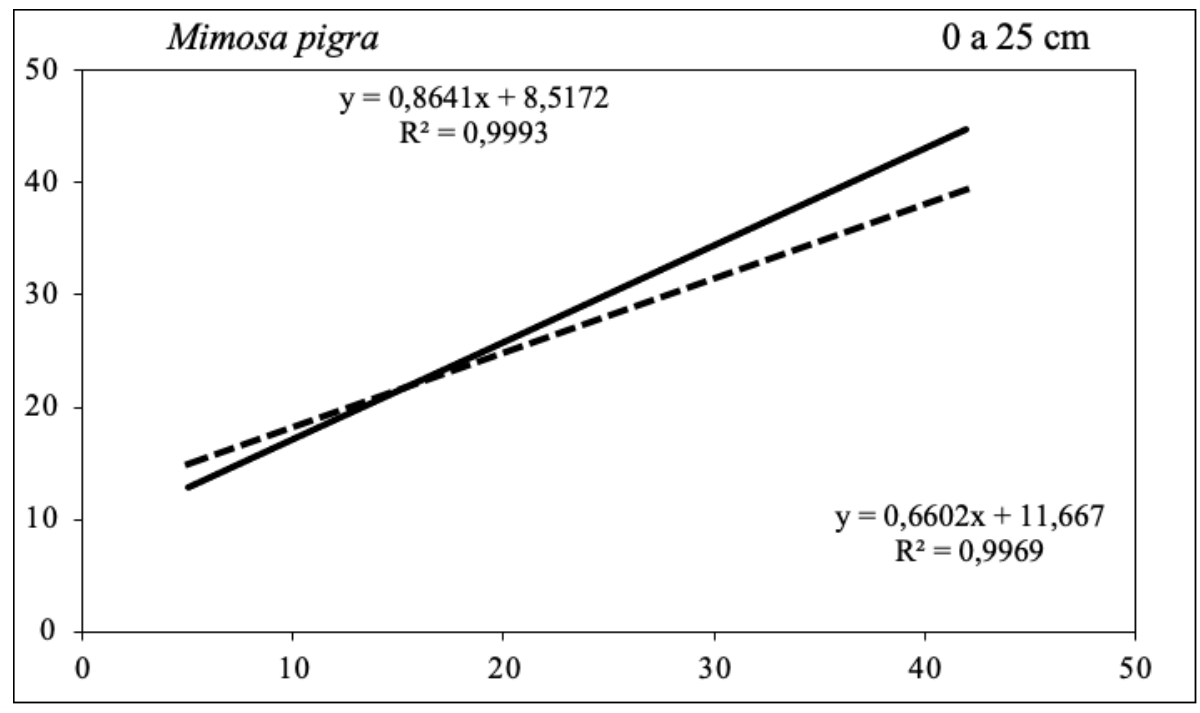



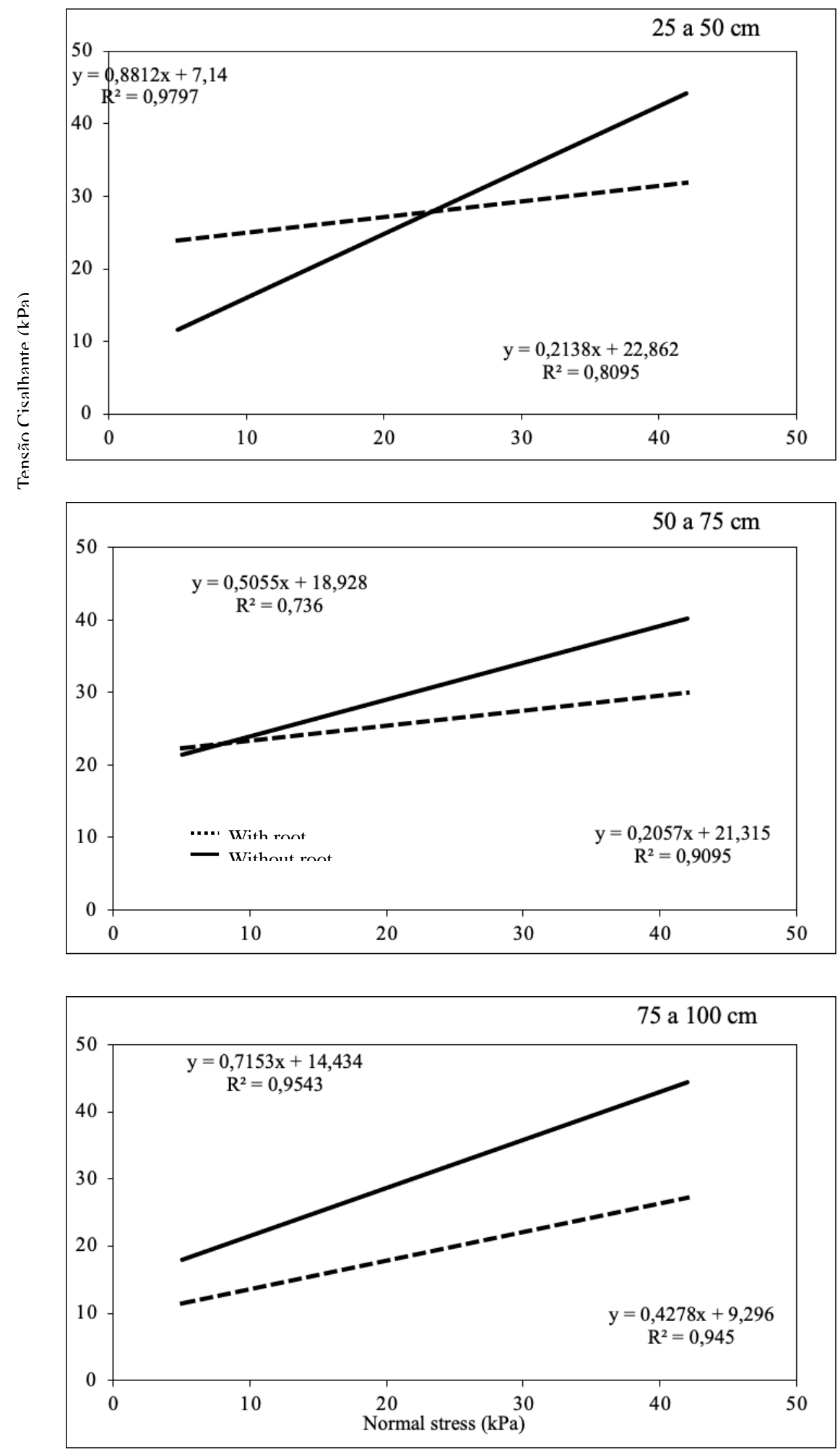

Figure. 7 Normal and shear stress for samples with and without roots of Mimosa Pigra at 


\section{MlMacrothink}

Journal of Agricultural Studies

ISSN 2166-0379

2021, Vol. 9, No. 1

depths of (A) $0 \mathrm{~m}$ to $0.25 \mathrm{~m}$, (B) $0.25 \mathrm{~m}$ to $0.50 \mathrm{~m}$, (C) $0.50 \mathrm{~m}$ to $0.75 \mathrm{~m}$, and (D) $0.75 \mathrm{~m}$ to

$$
1.0 \mathrm{~m}
$$

At depths of 0-0.25 m, the minimum and maximum shear resistance for the samples without roots were 13.0 and $45.02 \mathrm{kPa}$, respectively, considering corresponding normal stress of $5 \mathrm{kPa}$ and $42 \mathrm{kPa}$. By using a regression line and these results, we obtained the values of $c, 8.77 \mathrm{kPa}$, and $\phi, 40.05^{\circ}$. For the samples with roots, the minimum and maximum shear resistance were $14.95 \mathrm{kPa}$ and $39.66 \mathrm{kPa}$, respectively, for corresponding normal stress values of $5 \mathrm{kPa}$ and 42 $\mathrm{kPa}$. These results were used to determine the values of $c, 11.67 \mathrm{kPa}$, and $\phi, 33.43^{\circ}$. At these depths, a lower value of $\phi$ and a higher value of $c$ were observed in the presence of roots.

At depths of $0.50-0.75 \mathrm{~m}$, the samples without roots had minimum shear resistance of 16.9 $\mathrm{kPa}$ and maximum shear resistance of $37.19 \mathrm{kPa}$. The samples with roots had minimum and maximum shear resistance of $22.83 \mathrm{kPa}$ and $30.56 \mathrm{kPa}$, respectively, and $c$ values of $18.0 \mathrm{kPa}$ and $21.3 \mathrm{kPa}$ for samples without and with roots, respectively. For samples without and with roots, $\phi$ values of $25.9^{\circ}$ and $11.6^{\circ}$, respectively, were obtained. Therefore, at these depths, a higher value of $c$ and a lower value of $\phi$ were obtained with the presence of roots.

At depths of $0.75-1.0 \mathrm{~m}$, the minimum and maximum shear resistance values were $20.44 \mathrm{kPa}$ and $46.0 \mathrm{kPa}$, respectively, for the samples without roots. For the species with roots, we obtained a minimum shear resistance of $11.78 \mathrm{kPa}$ and a maximum shear resistance of 26.94 $\mathrm{kPa}$. In both situations, normal stress of $11 \mathrm{kPa}$ and $42 \mathrm{kPa}$ was considered. These results allowed us to determine the values of $c$ and $\phi$ as $14.61 \mathrm{kPa}$ and $34.89^{\circ}$, respectively, for samples without roots and $9.3 \mathrm{kPa}$ and $22.63^{\circ}$ for those with roots. These results indicate lower values of $c$ and $\phi$ in the presence of roots.

A comparison of shear envelopes through correlation analysis showed no significant differences $(\mathrm{P}<0,50)$ in the lines from the samples with and without roots.

Evaluating the samples with roots, Sesbania virgata presented the highest shear resistance, $41.61 \mathrm{kPa}$, when submitted to a load of $42 \mathrm{kPa}$ at depths of $0-0.25 \mathrm{~m}$. Out of those without roots, Mimosa pigra presented the highest shear resistance, $46 \mathrm{kPa}$, when submitted to a load of $42 \mathrm{kPa}$ at depths of $0.75-1.00 \mathrm{~m}$.

\section{Discussion}

We believe that the predominance of silty soil is due to the mobilization of soil that occurred during the slope redesign in 2010, which altered its characteristics from natural deposition to embankment. Nonetheless, because it is an alluvial soil mainly in a sedimentary stretch, this silty layer could have been part of a soil particle grouping that was formed during a long deposition period with low water flow speed.

Slaa et al. (2013), reported that silty soils are complex because silt is known as a cohesive material in erosion studies, but from a mineralogical perspective, it is classified as non-cohesive since it is composed primarily of quartz and feldspar.

Numerous authors have reported a positive relationship between the presence of roots and an increase in the shear resistance of the soil (Fan \& Tsai, 2016; Huang, Li, Chen, Zeng, \& Zhu, 
2018; Pirnazarov \& Sellgren, 2015). Nevertheless, it was observed that this relationship is fragile in samples randomly extracted from the site.

The premise that roots grow perpendicularly to the shear surface (Burak, Dodd, \& Quinton, 2021; Meijer, Muir Wood, Knappett, Bengough, \& Liang, 2019) could not be verified. In fact, the presence of roots allows a mobile slice of the sample to easily slide along the root, permitting the shear force to act with no resistance from the soil-soil friction; similar findings were presented by Campagnolo et al. (2018); Pollen and Simon (2010).

In the comparison of the average values of $\mathrm{c}$ between samples with and without roots, no statistical difference was observed for this attribute, which is the opposite to the values reported by Mao et al. (2012) and Palmer et al. (2016). These values for silty soil agree with those reported by Wang et al. (2020) and are lower than those reported by Davoudi (2011).

During the sampling time, the studied species were three years old, it is possible that their root structures were not sufficiently developed for providing greater shear resistance in the soil. This would help to explain the lack of statistical differences in cohesion for soil samples with and without roots. et al. (2008), while evaluating the increase of shear resistance in situ, it was observed that the cohesion values for soils with roots exceeded those for soils without roots after the plants had fully developed.

The attained results show that $\phi$ was affected by the presence of roots, different than the findings of Mahannopkul and Jotisankasa (2019); Bischetti (2009).

Considering that the shear envelope is composed by angular and linear coefficients of Coulomb's equation (Lambe, 1951), any constituent that modifies the composition of the sample will also modify the value of these coefficients and, consequently, the values of $\mathrm{c}$ and $\phi$.

Additionally, the presence of roots was expected to modify the behavior of the shear resistance envelope because its material was different from that of the soil sample. This corroborates the findings of Davoudi (2004), who observed a reduction in the values of $\phi$ in the presence of roots, which verifies a strong link between this attribute and the root diameter.

While examining the shear resistance of natural residual soil, which was a typical cohesive yellow lateritic soil, Silva and Carvalho (2007) observed a strong positive linear correlation between $\mathrm{c}$ and the soil specific weight, indicating dependency between these parameters for this soil type.

Nonetheless, the results of the present study show that soil specific weight is not linearly correlated to its cohesion or its internal friction angle, which is contrary to the results presented by Rocha et al. (2002).

This low structuring may be associated with the high concentration of silt, which is common in soils with less weathering ( $\mathrm{Ng}$ et al., 2020). Moreover, the soil-soil friction in the shear surface, which increases the soil resistance (Amiri, Emami, Mosaddeghi, \& Astaraei, 2019), was reduced due to the high voids content for samples at depths of $0.75 \mathrm{~m}$ to $1.0 \mathrm{~m}$.

Biological factors such as decomposition of dead roots and the presence of tunnels, nests, and 
chambers to contain soil macrofauna such as insects, termites, and worms were observed at the laboratory during the sample preparation. Such factors are responsible for the decrease in soil-soil resistance.

The position of the roots in relation to the shear plane influenced this behavior because, as previously stated, the samples were obtained from random positions within the blocks of soil. Therefore, the presence of roots was guaranteed although their direction, diameter, and level were not.

Zhang et al. (2013) examined silty samples with roots of Robinia pseucdoacacia in three different positions to the cutting plane-perpendicular, parallel, and crossed-and concluded that crossed roots, followed by perpendicular roots, are most suitable for the soil reinforcement.

In this sense, because roots are compound less dense elements than the soil, it is expected that samples with roots have lower specific weights than those constituted only by soil, which influences their shear resistances (W. W. Rocha et al., 2002).

However, we should note that the method used by Comino et al. (2010) and Mao et al. (2013) for in situ determination of soil shear resistance is subject to environmental conditions. Therefore, this method considers the root system as a whole and not only as segments, as presented in this study. Thus, the apparent differences in this study can be attributed to the used methodology. The in situ method enables a higher contact between the soil and root surface. As a result, the friction and soil resistance are increased (Mckenzie, Mullins, Tisdall, $\&$ Bengough, 2013). Studies using this method to investigate shear resistance tend to present higher values of soil cohesion and resistance in samples with roots.

\section{Conclusions}

The different species provided varied behaviors in the effects of the roots on Cohesion values. Solanum paniculatum produced the highest values of $\mathrm{c}$ for samples with roots except for $0 \mathrm{~m}$ to $0.25 \mathrm{~m}$.

As the soil appears without roots, the values of $\varphi$ (friction angles) rise in comparison to soils with roots, approximately $30 \%$, demonstrating that the presence of a cohesive root system influences the physical soil attributes. The species with the greatest significance was Sesbania virgata, which produced the most remarkable values of $\mathrm{c}$ for samples with and without roots. Mimosa pigra produced the highest c values for depths from $0.25 \mathrm{~m}$ to $0.50 \mathrm{~m}$ and $0.50 \mathrm{~m}$ to $0.75 \mathrm{~m}$.

The soil specific weight is not linearly correlated to its cohesion or its internal friction angle.

It has been noticed the complex relationship between the presented data, mainly the expected relation between the root structure, and its contribution in the soil cohesion to the erosion control on the river bank.

\section{Acknowledgments}

The authors thanks CNPq - Conselho Nacional de Desenvolvimento Científico e Tecnológico to support this research. 


\section{References}

Abedini, M., Said, M. A. M., \& Ahmad, F. (2012). Effectiveness of check dam to control soil erosion in a tropical catchment (The Ulu Kinta Basin). CATENA, 97, 63-70. https://doi.org/10.1016/j.catena.2012.05.003

ABNT, A. B. de N. T. (1984a). NBR 6459: Solo. Determinação do limite de plasticidade e indice de plasticidade em solos.

ABNT, A. B. de N. T. (1984b). NBR 6508: Solo. Grãos de solos que passam na peneira de 4,8 mm-Determinação da massa específica. Rio de Janeiro.

ABNT, A. B. de N. T. (1984c). NBR 7180: Solo. Determinação do limite de liquidez de solos. Rio de Janeiro.

ABNT, A. B. de N. T. (1984d). NBR 7181: Análise granulométrica em solos. Rio de Janeiro.

ABNT, A. B. de N. T. (1986). NBR 6457: Preparação de amostras para os ensaios de compactação e caracterização do solo. Rio de Janeiro.

Alam, S., Banjara, A., Wang, J., Patterson, W. B., \& Baral, S. (2018). Novel Approach in Sampling and Tensile Strength Evaluation of Roots to Enhance Soil for Preventing Erosion. Open Journal of Soil Science, 8(12), 330-349. https://doi.org/10.4236/ojss.2018.812024

American Society for Testing and Materials. (2017). ASTM D 6528: 2017 Standard Test Method for Consolidated Undrained Direct Simple Shear Testing of Fine Grain Soils. West Conshohocken.

Amiri, E., Emami, H., Mosaddeghi, M. R., \& Astaraei, A. R. (2019). Shear strength of an unsaturated loam soil as affected by vetiver and polyacrylamide. Soil and Tillage Research, 194, 104331. https://doi.org/10.1016/j.still.2019.104331

Araújo, F., Holanda, F. S. R., Pedrotti, A., Oliveira, S., Lino, J. B., \& da Rocha, I. P. (2017). Influence of properties physicals-mechanicals in the stability of the slope in the lower São Francisco. Scientia Agraria, 18(4), 107-113. https://doi.org/10.5380/rsa.v18i4.52140

Baranska, M., Schulz, H., Baranski, R., Nothnagel, T., \& Christensen, L. P. (2005). In situ simultaneous analysis of polyacetylenes, carotenoids and polysaccharides in carrot roots. Journal of agricultural and food chemistry, 53(17), 6565-6571.

https://doi.org/10.1021/jf0510440

Bischetti, G. B., Chiaradia, E. A., Epis, T., \& Morlotti, E. (2009). Root cohesion of forest species in the Italian Alps. Plant and Soil, 324(1-2), 71-89.

https://doi.org/10.1007/s11104-009-9941-0

Böhm, W. (2012). Methods of studying root systems (Vol. 33). Springer Science \& Business Media. 


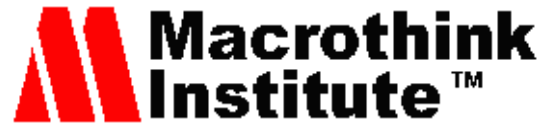

Burak, E., Dodd, I. C., \& Quinton, J. N. (2021). Do root hairs of barley and maize roots reinforce soil under shear stress? Geoderma, 383, 114740.

https://doi.org/10.1016/j.geoderma.2020.114740

Campagnolo, K., Kobiyama, M., Mazzali, L. H., \& Paixão, M. A. (2018). A influência da vegetação na estabilidade de encostas com ênfase em margem de rio. Encontro Nacional de Desastres (1.: 2018 jul.: Porto Alegre). Anais. Porto Alegre: ABRHidro,[2018].

Capilleri, P. P., Motta, E., \& Raciti, E. (2016). Experimental Study on Native Plant Root Tensile Strength for Slope Stabilization. Procedia Engineering, 158, 116-121.

https://doi.org/10.1016/j.proeng.2016.08.415

Carvalho, A. M., Santos, L. D. V., Holanda, F. S. R., Pedrotti, A., \& Antonio, G. M. (2020). Digital image processing for evaluation of Paspalum millegrana schrad root. Revista Caatinga, 33(01), 100-107. https://doi.org/10.1590/1983-21252020v33n111rc

Comino, E., Marengo, P., \& Rolli, V. (2010). Root reinforcement effect of different grass species: A comparison between experimental and models results. Soil and Tillage research, 110(1), 60-68. https://doi.org/10.1016/j.still.2010.06.006

Correa, J., Postma, J. A., Watt, M., \& Wojciechowski, T. (2019). Soil compaction and the architectural plasticity of root systems. Journal of Experimental Botany, 70(21), 6019-6034. https://doi.org/10.1093/jxb/erz383

Davoudi, M. H., Aghda, S. F., \& Pour, G. S. A. (2004). Landslide stabilization by tree root reinforcement. WIT Transactions on Ecology and the Environment, 75, 01-07.

Davoudi, Mohammad Hadi. (2011). Influence of willow root density on shear resistance parameters in fine grain soils using in situ direct shear tests. Research Journal of Environmental Sciences, 5(2), 157. https://doi.org/10.3923/rjes.2011.157.170

Fan, C.-C., \& Tsai, M.-H. (2016). Spatial distribution of plant root forces in root-permeated soils subject to shear. Soil and Tillage Research, 156, 1-15.

https://doi.org/10.1016/j.still.2015.09.016

Ferreira, C. de A., Valente, R. de M., \& Santos, R. S. (2017). Ocorrência de Faustinus apicalis (Faust)(Coleoptera: Curculionidae) e Nealcidion bicristatum (Bates)(Coleoptera: Cerambycidae) em solanáceas no norte do Brasil. EntomoBrasilis, 10(3), 244-247. https://doi.org/10.12741/ebrasilis.v10i3.678

Franco, E. (1983). Biogeografia do estado de Sergipe. E. Franco.

Ganapathy, T., Sathiskumar, R., Senthamaraikannan, P., Saravanakumar, S. S., \& Khan, A. (2019). Characterization of raw and alkali treated new natural cellulosic fibres extracted from the aerial roots of banyan tree. International journal of biological macromolecules, 138, 573-581. https://doi.org/10.1016/j.ijbiomac.2019.07.136 
Ghestem, M., Veylon, G., Bernard, A., Vanel, Q., \& Stokes, A. (2014). Influence of plant root system morphology and architectural traits on soil shear resistance. Plant and Soil, 377. https://doi.org/10.1007/s11104-012-1572-1

Gonzales, A. A., Dahlin, T., Barmen, G., \& Rosberg, J.-E. (2016). Electrical resistivity tomography and induced polarization for mapping the subsurface of alluvial fans: A case study in Punata (Bolivia). Geosciences, 6(4), 51. https://doi.org/10.3390/geosciences6040051

Hamidifar, H., Keshavarzi, A., \& Truong, P. (2018). Enhancement of river bank shear strength parameters using Vetiver grass root system. Arabian Journal of Geosciences, 11(20), 611. https://doi.org/10.1007/s12517-018-3999-z

Holanda, F. S. R., Santos, C. M. dos, Casado, A. P. B., Bandeira, A. A., Oliveira, V. S. de, Fontes, L. C. da S., ... Vieira, T. R. S. (2007). Análise Multitemporal e Caracterização dos Processos Erosivos no Baixo São Francisco Sergipano. Revista Brasileira de Geomorfologia, 8(2). https://doi.org/10.20502/rbg.v8i2.96

Holanda, F. S. R., Santos, L. da C. G., Araujo Filho, R. N., Pedrotti, A., Gomes, L. J., \& Conceição, F. G. (2011). Percepção dos ribeirinhos sobre a erosão marginal e a retirada da mata ciliar do Rio São Francisco no seu baixo curso. https://doi.org/10.5380/raega.v22i0.21773

Holanda, F. S. R., Santos, L. G. da C., Santos, C. M. dos, Casado, A. P. B., Pedrotti, A., \& Ribeiro, G. T. (2005). Riparian vegetation affected by bank erosion in the Lower São Francisco River, Northeastern Brazil. Revista Árvore, 29(2), 327-336. https://doi.org/10.1590/S0100-67622005000200016

Huang, H., Li, A., Chen, L., Zeng, C., \& Zhu, M. (2018). Push-Out Tests for Shear Connectors in GFRP-Concrete Composite Bridge Deck Slabs. Journal of Advanced Concrete Technology, 16(8), 368-381. https://doi.org/10.3151/jact.16.368

Hubble, T. C. T., Airey, D. W., Sealey, H. K., De Carli, E. V., \& Clarke, S. L. (2013). A little cohesion goes a long way: Estimating appropriate values of additional root cohesion for evaluating slope stability in the Eastern Australian highlands. Ecological Engineering, 61, 621-632. https://doi.org/10.1016/j.ecoleng.2013.07.069

Jordanova, D., Goddu, S. R., Kotsev, T., \& Jordanova, N. (2013). Industrial contamination of alluvial soils near $\mathrm{Fe}-\mathrm{Pb}$ mining site revealed by magnetic and geochemical studies. Geoderma, 192, 237-248. https://doi.org/10.1016/j.geoderma.2012.07.004

Kokutse, N. K., Temgoua, A. G. T., \& Kavazović, Z. (2016). Slope stability and vegetation: Conceptual and numerical investigation of mechanical effects. Ecological Engineering, 86, 146-153. https://doi.org/10.1016/j.ecoleng.2015.11.005

Lambe, T. W. (1951). Soil testing for engineers (Vol. 72). LWW. https://doi.org/10.1097/00010694-195111000-00018

Leung, F. T. Y., Yan, W. M., Hau, B. C. H., \& Tham, L. G. (2018). Mechanical pull-out capacity and root reinforcement of four native tree and shrub species on ecological 
rehabilitation of roadside slopes in Hong Kong. Journal of Tropical Forest Science, 25-38. https://doi.org/10.26525/jtfs2018.30.1.2538

Lonsdale, W. M., Harley, K. L. S., \& Gillett, J. D. (1988). Seed Bank Dynamics in Mimosa pigra, an Invasive Tropical Shrub. Journal of Applied Ecology, 25(3), 963-976. https://doi.org/10.2307/2403758

Lyda, T. A., Wagner, E. L., Bourg, A. X., Peng, C., Tomaraei, G. N., Dean, D., ... Jr.Marcotte, W. R. (2017). A Leishmania secretion system for the expression of major ampullate spidroin mimics. PLoS ONE, 12(5), 1-15. https://doi.org/10.1371/journal.pone.0178201

Mahannopkul, K., \& Jotisankasa, A. (2019). Influences of root concentration and suction on Chrysopogon zizanioides reinforcement of soil. Soils and Foundations, 59(2), 500-516. https://doi.org/10.1016/j.sandf.2018.12.014

Mao, Z., Jourdan, C., Bonis, M.-L., Pailler, F., Rey, H., Saint-André, L., \& Stokes, A. (2013). Modelling root demography in heterogeneous mountain forests and applications for slope stability analysis. Plant and Soil, 363(1), 357-382. https://doi.org/10.1007/s11104-012-1324-2

Mao, Z., Saint-Andre, L., Genet, M., Mine, F.-X., Jourdan, C., Rey, H., ... Stokes, A. (2012). Engineering ecological protection against landslides in diverse mountain forests: Choosing cohesion models. Ecological Engineering, 45, 55-69.

https://doi.org/10.1016/j.ecoleng.2011.03.026

Martins-Oliveira, A. T., Stefanello, L. E. S., Santos, T. M., Pinto, V. R., Souza, C. A., \& Sousa, J. B. (2020). Morphological, physical and chemical attributes of the soil profile to the right margin of the Paraguay river, Baia da Campina, Cáceres (MT). Scientific Electronic Archives, 13(10), 61-68. https://doi.org/10.36560/131020201076

Matasci, B., Jaboyedoff, M., Loye, A., Pedrazzini, A., Derron, M.-H., \& Pedrozzi, G. (2015). Impacts of fracturing patterns on the rockfall susceptibility and erosion rate of stratified limestone. Geomorphology, 241, 83-97. https://doi.org/10.1016/j.geomorph.2015.03.037

Mckenzie, B. M., Mullins, C. E., Tisdall, J. M., \& Bengough, A. G. (2013). Root-soil friction: Quantification provides evidence for measurable benefits for manipulation of root-tip traits. Plant, Cell \& Environment, 36(6), 1085-1092. https://doi.org/10.1111/pce.12037

Meijer, G. J., Muir Wood, D., Knappett, J. A., Bengough, G. A., \& Liang, T. (2019). Analysis of coupled axial and lateral deformation of roots in soil. International Journal for Numerical and Analytical Methods in Geomechanics, 43(3), 684-707. https://doi.org/10.1002/nag.2880

Meijer, G. J., Wood, D. M., Knappett, J. A., Bengough, A. G., \& Liang, T. (2019). Root branching affects the mobilisation of root-reinforcement in direct shear. E3S Web of Conferences, 92, 12010. EDP Sciences. https://doi.org/10.1051/e3sconf/20199212010

Moshi, A. A. M., Ravindran, D., Bharathi, S. S., Indran, S., Saravanakumar, S. S., \& Liu, Y. (2020). Characterization of a new cellulosic natural fiber extracted from the root of Ficus religiosa tree. International Journal of Biological Macromolecules, 142, 212-221. https://doi.org/10.1016/j.ijbiomac.2019.09.094 
Nascimento Prata. (2015). ASE herbarium-Universidade Federal de Sergipe-Herbário Virtual REFLORA [Herbarium]. Recuperado 5 de novembro de 2020, de http://ipt.jbrj.gov.br/reflora/resource?r=ase_herbarium\&v=1.134\#citation

Ng, C. W. W., Owusu, S. T., Zhou, C., \& Chiu, A. C. F. (2020). Effects of sesquioxide content on stress-dependent water retention behaviour of weathered soils. Engineering Geology, 266, 105455. https://doi.org/10.1016/j.enggeo.2019.105455

Nguyen, T. S., Likitlersuang, S., \& Jotisankasa, A. (2019). Influence of the spatial variability of the root cohesion on a slope-scale stability model: A case study of residual soil slope in Thailand. Bulletin of Engineering Geology and the Environment, 78(5), 3337-3351. https://doi.org/10.1007/s10064-018-1380-9

Normaniza, O., Faisal, H. A., \& Barakbah, S. S. (2008). Engineering properties of Leucaena leucocephala for prevention of slope failure. Ecological engineering, 32(3), 215-221. https://doi.org/10.1016/j.ecoleng.2007.11.004

Palmer, M. A., Zedler, J. B., \& Falk, D. A. (2016). Ecological theory and restoration ecology. In Foundations of restoration ecology (p. 3-26). Springer.

https://doi.org/10.5822/978-1-61091-698-1_1

Petrone, A., \& Preti, F. (2013). Soil Bioengineering Measures in Latin America: Authocthonal Cuttings Suitability. In C. Margottini, P. Canuti, \& K. Sassa (Orgs.), Landslide Science and Practice: Volume 7: Social and Economic Impact and Policies (p. 325-329). Berlin, Heidelberg: Springer. https://doi.org/10.1007/978-3-642-31313-4_43

Pirnazarov, A., \& Sellgren, U. (2015). Reduced testing and modelling of the bearing capacity of rooted soil for wheeled forestry machines. Journal of Terramechanics, 60, 23-31. https://doi.org/10.1016/j.jterra.2015.05.002

Pollen-Bankhead, N., \& Simon, A. (2010). Efeitos hidrológicos e hidráulicos de redes radiculares ribeirinhas na estabilidade do streambank: É o reforço mecânico da raiz toda a história. Geomorfologia, 353-362(116). https://doi.org/10.1016/j.geomorph.2009.11.013

Qi, C., \& Tang, X. (2018). Slope stability prediction using integrated metaheuristic and machine learning approaches: A comparative study. Computers \& Industrial Engineering, 118, 112-122. https://doi.org/10.1016/j.cie.2018.02.028

Ribeiro, L. F., Holanda, F. S. R., de Araújo Filho, R. N., Rocha, I. P., \& Gois, S. S. (2011). Alterações de paisagens ribeirinhas: O caso do Rio Paramopama, estado de Sergipe. Floresta, 41(2). https://doi.org/10.5380/rf.v41i2.21870

Rocha, Igor P. da, Holanda, F. S. R., Araújo Filho, R. N., Casado, A. P. B., \& Bandeira, A. A. (2013). Meteorological and hydrological variables on occurrence of riverbank erosion along lower São Francisco river. Revista Brasileira de Engenharia Agrícola e Ambiental, 17(2), 137-144. https://doi.org/10.1590/S1415-43662013000200004

Rocha, Igor Pinheiro da, Holanda, F. S. R., Rolim, M. M., Lino, J. B., \& de Araújo Filho, R. N. (2018). Magnitude and Spatiotemporal Variation of the Erosion on the Slope of the Lower São 
Francisco River, Northeastern Brazil. Journal of Experimental Agriculture International, 1-11. https://doi.org/10.9734/JEAI/2018/41944

Rocha, W. W., JUNIOR, M. D., Lima, J. M., Miranda, E. E. V., \& Silva, A. R. (2002). Resistência ao cisalhamento e grau de intemperismo de cinco solos na região de Lavras (MG). Revista brasileira de ciência do solo, 26(2), 297-303. https://doi.org/10.1590/S0100-06832002000200002

Salis, S. M., Silva, M. P. da, Mattos, P. P. de, Silva, J. S., Pott, V. J., \& Pott, A. (2004). Fitossociologia de remanescentes de floresta estacional decidual em Corumbá, Estado do Mato Grosso do Sul, Brasil. Brazilian Journal of Botany, 27(4), 671-684. https://doi.org/10.1590/S0100-84042004000400008

Samadi, A., Amiri-Tokaldany, E., Davoudi, M. H., \& Darby, S. E. (2011). Identifying the effects of parameter uncertainty on the reliability of modeling the stability of overhanging, multi-layered, river banks. Geomorphology, 134(3), 483-498. https://doi.org/10.1016/j.geomorph.2011.08.004

Sartori, Â. L. B., Pott, V. J., Pott, A., \& de Carvalho, F. S. (2018). Check-list das Angiospermas do Chaco de Mato Grosso do Sul. Iheringia. Série Botânica., 73, 22-33. https://doi.org/10.21826/2446-8231201873s22

Silva, A. J. N. da, \& Carvalho, F. G. de. (2007). Coesão e resistência ao cisalhamento relacionadas a atributos físicos e químicos de um Latossolo Amarelo de tabuleiro costeiro. Revista Brasileira de Ciência do Solo, 31(5), 853-862. https://doi.org/10.1590/S0100-06832007000500003

Slaa, S. T., He, Q., van Maren, D. S., \& Winterwerp, J. C. (2013). Sedimentation processes in silt-rich sediment systems. Ocean Dynamics, 63(4), 399-421. https://doi.org/10.1007/s10236-013-0600-x

Snedecor, G. W., \& Cochran, W. G. (1989). Statistical Methods, eight edition. Iowa state University press, Ames, Iowa.

Soil Survey Staff. (2014). Keys to Soil Taxonomy (12th ed). Washington DC: USDA-Natural Resources Conservation Service.

Stokes, A., \& Mattheck, C. (1996). Variation of wood strength in tree roots. Journal of Experimental Botany, 47(5), 693-699. https://doi.org/10.1093/jxb/47.5.693

Stokes, Alexia, Douglas, G. B., Fourcaud, T., Giadrossich, F., Gillies, C., Hubble, T., ... McIvor, I. R. (2014). Ecological mitigation of hillslope instability: Ten key issues facing researchers and practitioners. Plant and Soil, 377(1-2), 1-23. https://doi.org/10.1007/s11104-014-2044-6

Sun, H., Wang, D., Shang, Y., Cai, Y., \& Wei, Z. (2019). An improved siphon drainage method for slope stabilization. Journal of Mountain Science, 16(3), 701-713. https://doi.org/10.1007/s11629-018-5171-3 


\section{Macrothink

Vannoppen, W., Baets, S. D., Keeble, J., Dong, Y., \& Poesen, J. (2017). How do root and soil characteristics affect the erosion-reducing potential of plant species? Ecological Engineering, 109, 186-195. https://doi.org/10.1016/j.ecoleng.2017.08.001

Velinova, R., Todorova, S., Drenchev, B., Ivanov, G., Shipochka, M., Markov, P., ... Naydenov, A. (2019). Complex study of the activity, stability and sulfur resistance of $\mathrm{Pd} / \mathrm{La} 2 \mathrm{O} 3-\mathrm{CeO} 2-\mathrm{A} 12 \mathrm{O} 3$ system as monolithic catalyst for abatement of methane. Chemical Engineering Journal, 368, 865-876. https://doi.org/10.1016/j.cej.2019.03.017

Wang, L., Guo, F., \& Wang, S. (2020). Prediction model of the collapse of bank slope under the erosion effect of wind-induced wave in the Three Gorges Reservoir Area, China. Environmental Earth Sciences, 79(18), 421. https://doi.org/10.1007/s12665-020-09169-y

Wang, Y., Xu, Y., Tabari, H., Wang, J., Wang, Q., Song, S., \& Hu, Z. (2020). Innovative trend analysis of annual and seasonal rainfall in the Yangtze River Delta, eastern China. Atmospheric Research, 231. Scopus. https://doi.org/10.1016/j.atmosres.2019.104673

Zhang, Z. Y., Wu, D. Z., \& Wang, C. (2013). Study on the Shear Strength Properties of the Silt in Hangzhou, China. Applied Mechanics and Materials, 405-408, 349-352. https://doi.org/10.4028/www.scientific.net/AMM.405-408.349

\section{Copyright Disclaimer}

Copyright for this article is retained by the author(s), with first publication rights granted to the journal.

This is an open-access article distributed under the terms and conditions of the Creative Commons Attribution license (http://creativecommons.org/licenses/by/4.0/). 